\title{
A Study of Evaluation Methods of Teaching Practice of Distance Teacher Education Institutions
}

\author{
Fouzia Younas \\ Assistant Professor IER \\ Punjab University Lahore \\ fouziyounus@gmail.com
}

\begin{abstract}
This study was aimed to investigate evaluation methods of teaching practice of distance teacher education institutions in Pakistan. Major objectives of the study were: to examine the evaluation methods of teaching practice used in distance teacher education institutions; to analyze the effectiveness of teaching practice at distance teacher education institutions; and to find out the problems/weaknesses in evaluation of teaching practice in these institutions. The population was consisted of all the supervisors of distance teacher education institution offering teacher education programmes. Allama Iqbal Open University Islamabad in Pakistan is example of distance education. Two questionnaires were developed on the basis of related literature for prospective teachers and supervisors to get the responses. The data were collected by administering the validated questionnaires. Randomly 200 respondents were selected. The data were analyzed and interpreted by using percentages and two-way chi-square square techniques. Inferred results were discussed and reported. The major conclusions of the study were that the prospective teachers of distance teacher education institutions are not very satisfied with the duration of teaching practice. Some of the recommendations are that there is a need to put in place a continuous system of monitoring and evaluation of teaching practice including observations of prospective teachers for distance teacher education institutions. The time period of teaching practice may be increased. Self-evaluation of prospective teachers may be included in the evaluation of teaching practice.
\end{abstract}

Keywords: Evaluation, Teaching Practices, Distance Teacher Education, Self-evaluation

\section{Introduction}

The teaching practice plays important role in reducing gap between theory and practice, it also provides the context for prospective teachers to develop their personal teaching competencies (Smith \& Lev-Ari, 2005). According to Taneja (2000) there are many terminologies used for this activity i.e. teaching practice, vocational training, field experience, school based practice, student teaching and practice teaching. Teaching practice is the most important and practical aspect of teacher training programmes and it is an assortment of factual and dramatic characteristics. The evaluation of teaching practice for the purpose of certification is a very problematic subject. To a great extent this is a consequence of the apprenticeship approach. Prospective teachers have inevitably been graded according to the criteria held by individual teachers or specific institutions and the criteria have not always been made explicit (Murtaza. Ali. 2005).

There is still a growing controversy about the most effective way of assessing prospective teachers on teaching practice. Educator tends to have different ideas as to what constitutes a successful lesson and hence a competent teacher. The evaluation procedure used in teaching practice is largely impressionistic in nature; hence the problem of objectivity is there when marks 
or grades are awarded. Tutor/supervisors are generally given assessment schedules which include some criteria against which prospective teacher's performances are to be judged, often along a five point scale: that is, 5 to 0 or $\mathrm{A}$ to $\mathrm{F}$, ranging from excellent to unsatisfactory. Usually these assessment forms include only broad categories of criteria to be evaluated, with a few sub-divisions under each. The weight to be given to each category is not always specified indeed, perhaps it should not be, since the relative importance of each can vary with the types of lesson being taught.

Although supervisors have different ideas of what they want to see in a good lesson, they seem to agree on the broad areas to consider. These areas are:

i. The personal qualities of the prospective teachers,

ii. The preparation involved in the form of a lesson plan,

iii. The choice of method and use of instructional materials,

iv. Class management and control,

v. Evaluation techniques,

vi. The general attitude of the prospective teacher.

This study was undertaken to find out the evaluation methods of teaching practice in distance teacher education institutions of Pakistan. Moreover, the strengths and weaknesses of different evaluation methods used by these both systems of education were revealed. Findings of the study have provided a picture of existing practices of evaluation of teaching practice and leaded to some recommendations for teacher education institutions both in formal and distance teacher education systems. Evaluation of teaching practice would be hopefully improved. Evaluation of teaching practice has always been a challenging task for teacher education institutions. There was a dire need to explore the strengths and weaknesses in assessing the teaching practice component of teacher education programmes of distance teacher education system. Therefore, this study was aimed at investigating the evaluation methods of teaching practice of distance teacher education programmes prevailing in the country.

\section{Review of Related Literature}

Smith \& Lev-Ari (2005) stated that "the teaching practice plays important role in reducing gap between theory and practice, it also provides the context for prospective teachers to develop their personal teaching competencies. Prospective teachers are provided appropriate knowledge of theory during training in Teachers Training Institutes but only few of them can deliver lesson by making relationship of learning with practical skills and real life examples. This situation compelled me to conduct action research in this area. This research was aimed to improve teaching skills by using relevant examples from practical life skills".

\section{Distance Education}

Eraut (2000) defines distance education or learning as any type of education taking place outside of the formal education. Distance education typically involves workshops, community courses, interest-based courses, short courses, or conference style seminars and occurs in a formal setting such as an educational institute, but is not formally recognized (www.en.wikipedia.org). For teachers, the scope of non-formal is many-fold because they need to keep update themselves with new learning materials and techniques, for which distance education is essential instrument for their lifelong learning.

Nomikou (2008) writes that Distance education gives an opportunity to the teachers, to develop their values, skills and competencies other than those developed through formal education. Those skills (also called soft skills) include a wide range of competencies such as interpersonal, 
team, organizational and conflict management, intercultural awareness, leadership, planning, organizing, co-ordination and practical problem solving skills, team work, self-confidence, discipline and responsibility.

\section{Elements of Teaching Practice}

According to teaching practice handbook of queen's university (2010) the elements of teaching practice are.

1. Professionalism

(a) Initiative and Dependability

(b) Discretion \& professional Judgment

(c) Response to Mentorship

2. Supporting a community of Learners

(a) Promoting a Safe and Trusting Leaning Community

(b) Promoting Student Independence

3. Planning and Preparing

(a) Use of Curriculum

(b) Sequencing of Steps in a lesson

(c) Differentiation

(d) Resources

4. Lesson Presentation

(a) Instructional Strategies

(b) Lesson Management

(c) Awareness of Classroom Dynamics

(d) Appropriate and effective use of Language

(e) Engaging all learners

5. Assessment

(a) Assessment for Learning

(b) Assessment as Learning

(c) Assessment of Learning

\section{Evaluation of Teaching Practice}

Saeed (2002) narrates the role of evaluation is the central one because the success of whole educational process rests with the aspect that how for the learning outcomes in a certain subject areas have been achieved in the school. If learning outcomes are not being properly and continuously assessed, we can neither guarantee the desired improvement in the students learning nor the teacher's methodology of teaching. Purposeful instruction takes place only when learning is properly assessed. It is a well-known fact that instruction is guided by assessment and evaluation. The evaluation process usually involves preparation, observation, data collection, reporting, and follow-up.

Gay (2003) defines that Evaluation as the broadest term includes not only the process of determining what the actual educational outcomes are and of comparing them with the expected outcomes, but it involves judgments about the nature and desirability of any demonstrated changes. Judgments of this kind obviously bear directly on educational objectives. Evaluation is the systematic process of collecting and analyzing data in order to determine whether and to what degree objectives have been achieved. It is the systematic process of collecting and analyzing data in order to make decision. 
Akbar (2002) suggested that evaluation mode of teaching practice should be internal and evaluation criteria should be made part of teaching practice manual to be provided to prospective teachers. A suggested criterion is given here.

1. Quality and quantity of content (mastery over the content)

2. Voice and oral expressions (volume, tone, choice of words, easily understood, power of expression, pronunciation).

3. Lesson plan and preparation.

4. Teaching aids (Wise choice, effective use, use of available resources, black board summary).

5. General appearance (dress, facial expression, body gestures).

6. Class discipline (maintaining of students interest, participation, student response, management, makes learning exciting and lively, behavior with students)

7. Use of teaching methods(wise selection, relevant with content)

8. Ability to motivate class students (motivation for good work-habit, achievement of desirable attitude)

9. Quality of questions (clear, varied and thought-provoking questions, encouragement of pupil questions, handling questions)

10. Student response/behavior (like the teachers, respect the teacher, take interest in the lessons.

Goe, Bell and Little (2005) identified the following seven methods of evaluation of teaching practice.

1. Classroom observation by internal/external evaluators.

2. Student ratings.

3. Head teacher's judgment.

4. Teacher self-report.

5. Analysis of classroom artifacts e.g. lesson plans, assignments.

6. Teacher portfolios.

7. Value added model. (Assessing gain in student achievement).

\section{Teaching practice Through Distance Teacher Education System}

Allama Iqbal Open University (AIOU) is an example of offering distance education in Pakistan. It is offering several programs including teacher education programs. Allama Iqbal Open University was established to provide part time educational facilities through correspondence courses, tutorials, seminars, workshops, laboratories, television, radio broadcasts, and other mass communication media. People Open University was established in 1974 under an act of parliament. It was renamed as Allama Iqbal Open University in 1977.

\section{Components of AIOU}

According to Murtaza, Ali 2005 the Allama Iqbal Open University being a distance education institution relies heavily on all varieties of available media to reach to its students in an effective manner. Its main components are:

a. Correspondence material including self-learning study package and supplementary study materials, (Readers, Text Books and Study Guides).

b. Radio and television broadcasts generally related to the study materials of the package.

c. Satellite transmission: AIOU is putting on air its educational media material on PTV-2 which is beaming out its transmission through satellite to more than 45 countries. 
d. Non-broadcast Media: Including slides, audiocassettes, flip charts, and leaflets (generally for basic courses) and also audio video cassettes as integral part of learning material.

e. Tutorial Instruction: Through contact session and academic guidance facilities at study centers (mostly in the afternoons).

f. Face-to-face teaching: has recently started for those courses, which require intensive practical/lab work or skill development.

g. Group training workshops: for post graduate programme, generally at M.A/M.Sc./M.Phil. and $\mathrm{Ph} . \mathrm{D}$. levels.

h. Internship of short term and long-term duration in industrial or business concerns for B.B.A and M.B.A programmes.

i. Course assignments: as an instrument of instruction, continuous assessment and general academic guidance of students. The tutors evaluate them.

Final Examination: held for each course, at the end of the semester. (Allama, 1985)

\section{Regional Network}

The university has 32 Regional Centers and 54 part time Regional Coordinating Officers. The Regional Coordination officers are on part time basis throughout the country. About 900-study center are established during a semester and are managed through the university's regional compasses and centers. Each student is appointed in both the semesters. Students have the opportunity to meet the tutors. They organize workshops/practical training in the regions. (Chaudhry, 2004).

\section{Methods of Instruction}

In distance learning system, the courses are taught through self-instructional materials, media component (where applicable), tutorial meetings and workshops.

\section{a) Self-instructional Material}

The study materials are included of study guides, allied materials and media support (if any) tutorials (if applicable).

Tutorials provide useful guidance in the form of lectures, discussions, questions-answer sessions and general clarification of any course-related issues if required.

b) Workshops (Compulsory)

At the end of each semester there is a compulsory workshop for each course. These may be organized at the main campus or where ever the University deems feasible. The workshops are compulsory components of each course.

\section{Evaluation Procedure}

Procedure to prepare the result of a course is given as under:

a) Weightage for course assignments and final examinations is 30:70 respectively.

b) Minimum required marks to pass the assignments and final examination are $40 \%$

Aggregate of the components should be

Weightage $(30 \%)$ of the marks secured in course

Assignments (40\%)

Weightage $(70 \%)$ of the marks secured in final

Examination (40\%)

Total

(Faculty of Education, AIOU. 2004a)
$40 \%$

$\begin{array}{ll}\frac{40 \times 30}{100} & =12 \% \\ \frac{40 \times 70}{100} & =28 \% \\ & =40 \%\end{array}$




\section{Teaching practice}

Two years Masters in Education Program comprises of eleven full credit courses. Ten full credit for theory (2000 marks) and one full credit (200 marks) for practical experience (Teaching Practice). Its duration is

Two weeks + Four Weeks $\quad=\quad$ Six Weeks

(Workshop) (Teaching Practice)

The composition and weightage of teaching practice is as under:

\begin{tabular}{|c|c|}
\hline Composition & Weightage \\
\hline Workshop & $25 \%$ \\
\hline Practice Lessons (40 lessons) & $25 \%$ \\
\hline Final Lesson-I & $25 \%$ \\
\hline Final Lesson-II & $25 \%$ \\
\hline
\end{tabular}

Students have to qualify in each component separately.

\section{Workshop}

It is the re-orientation of knowledge that a student has gained during the study of courses. At the same time, workshop is the beginning of practice work. The workshop is conducted under the supervision of a senior educationalist. The name of the tutor along with the name of the school in which the workshop is conducted is informed by the concerned Regional Director.

Two supervisors assist tutor. Tutor informs the details of the workshop at least two weeks before the commencement of the workshop. He/she evaluates the performance of the students keeping in view the attendance, discipline, level of participation, level of contribution and other activities carried out during the workshop. Students have to write down forty lessons with their details on a register, which are maintained by each student. The head of the institution and the tutor examine each of forty lessons. Head of institutions issues certificate showing that specific student has completed forty lessons up to the satisfaction. This makes student eligible to deliver the final lessons.

\section{Assessment}

Final lessons are observed by an evaluation team headed by a senior professor of a university or College of Education where M.Ed./M.A. (Education) classes are being taught. Head of the institution, supervisors, DEO or his/her nominee and AIOU representative are the members of the team. Final lessons are written in files (each in separate file) and are submitted to the concerned Regional Director along with the register of 40 lessons. Moreover, A.V. aids prepared for the lessons are also deposited in the office of concerned Regional Director.

Components of teaching practice are compulsory. In the workshop following aspects are covered:

1. Assessing student's needs.

2. Assessing content needs.

3. Developing student profile.

4. Writing behavioral objectives.

5. Planning the lesson.

6. Selection of appropriate teaching aids.

7. Writing for Radio.

8. Writing for T.V.

9. Developing low cost teaching aids where appropriate.

10. Evaluation. 
11. On the last day of workshop, every student has to submit the outline of 40 lessons to the tutor which s/he will deliver during the teaching practice.

12. Minutes of every session are recorded by the students, vetted by the tutor and are submitted to the Regional Director.

13. Tutor and supervisors award marks out of 25 to the students on the basis of his/her performance during the workshop.

\section{Final Lessons}

Final lessons are two in number. Topic of each lesson depends on student's choice. University has no provision of TA/DA or any other expenditure incurred during the workshop. Sample evaluation Performa is also enclosed with (Faculty of Education, 2004b).

\section{Objectives of the Study}

The study accomplished the following objectives:

1. To analyze the effectiveness of teaching practice of distance teacher education institutions.

2. To find out the issues of evaluation of teaching practice of distance teacher education institutions.

3. To recommend the ways to improve the evaluation methods of teaching practice for the systems.

\section{Method and Procedure}

This research employed quantitative approach in order to collect data and the nature of this research is a descriptive research or survey study.

\section{Population}

The population of this research study was all the 2000 teacher educators i.e., university or college teaching practice supervisors of distance teacher education institutions offering teacher education programmes i.e.,B.Ed. (Hons) and Masters in Education and all the 4000 prospective teachers experiencing or have experienced the teaching practice ofdistance teacher education institutions offering teacher education programmes i.e.,B.Ed. (Hons.) and Masters in Education.

\section{Sample}

The sample was drawn from population by random sampling technique. In the distance teacher education institution (Allama Iqbal Open University) was taken as sample of the study. Following regional centers of AIOU were included:

- Allama Iqbal Open University - Rawalpindi Region

- Allama Iqbal Open University - Lahore Region

- Allama Iqbal Open University - Multan Region

- Allama Iqbal Open University - Attock Region

Table 1 Sample Size

\begin{tabular}{lc}
\hline & Total \\
& AIOU \\
\hline Student-teachers & 200 \\
\hline
\end{tabular}


Supervisor- 100

teachers

Total

300

AIOU =Allama Iqbal Open University,

\section{Research Instrument}

Two self-made questionnaires were developed based on objectives of the study and related literature comprising five points Likert type scale.

\section{Validity \& Reliability}

The content validity of the research tools was ensured through expert's opinions. According to the suggestions of the experts tool was changed and modified. The reliability of the tool was checked through Cronbach Alpha. Its value was found to 0.84 .

\section{Data Analysis}

The data obtained was tabulated, interpreted and analyzed with SPSS on the basis of mean, percentage method, and chi-square. The chi square $\left(\chi^{2}\right)$ technique was also used for data analysis. It was used to determine whether there is a significant difference between the expected and observed frequencies in one or more than one categories. The open-ended items responses were analyzed by using NVivo and all the results were recorded.Raw data was transformed into meaningful data by using SPSS 13.0(Statistical Packages for the Social Sciences). The data obtained was tabulated, interpreted and analyzed on the basis of Mean, percentage method and chi-square. The highest value was judged as indicator of difference among the responses of the respondents.

\section{Prospective Teachers' Opinion of Distance Teacher Education Systems}

Table 2:You are Satisfied with the Existing System of Teaching Practice

\begin{tabular}{lccccccc}
\hline Prospective teachers of: & $\mathrm{N}$ & SA & A & UN & DA & SDA & $\chi^{2}$ \\
Distance & & 25 & 119 & 7 & 36 & 13 & 100.58 \\
TeacherEducation & 200 & $12.5 \%$ & $59.5 \%$ & $3.5 \%$ & $18 \%$ & $6.5 \%$ & \\
System & & & & &
\end{tabular}

* Significant $\quad \mathrm{df}=4 \quad$ Table value at 0.05 level $=9.49$

Table 2 shows the calculated value of $\chi^{2}$ was found to be 100.58 which is greater than table value at 0.05 level. The Prospective teachers of distance teacher education system agreed with the statement "You are satisfied with the existing system of teaching practice".

Table 3:Duration of Teaching Practice you received is enough for your Training

\begin{tabular}{lccccccc}
\hline Prospective teachers of: & $\mathrm{N}$ & SA & A & UN & DA & SDA & $\chi^{2}$ \\
\hline $\begin{array}{l}\text { Distance } \\
\text { TeacherEducation }\end{array}$ & 200 & 28 & 49 & 9 & 73 & 41 & 5.50 \\
System & & $14 \%$ & $24.5 \%$ & $4.5 \%$ & 36.5 & $20.5 \%$ & \\
$* \begin{array}{l}\text { Non-Significant } \\
\text { Tf=4 }\end{array}$ & $\mathrm{T}$ & Table value at 0.05 level $=9.49$
\end{tabular}


Table 3 shows the calculated value of $\chi^{2}$ was 5.50 which is less than the table value at 0.05 level as the trend of respondents was toward disagreement. The statement "Duration of teaching practice you received is enough for your training" was rejected.

Table 4: Written Instructions are provided to Prospective Teachers before the Commencement of Teaching Practice

\begin{tabular}{lccccccc}
\hline Prospective teachers of: & N & SA & A & UN & DA & SDA & $\chi^{2}$ \\
\hline Distance & & 28 & 40 & 13 & 62 & 57 & 70.10 \\
$\begin{array}{l}\text { TeacherEducation } \\
\text { System }\end{array}$ & 200 & $14 \%$ & $20 \%$ & $6.5 \%$ & $31 \%$ & $28.5 \%$ & \\
\hline
\end{tabular}

* Significant $\quad \mathrm{df}=4 \quad$ Table value at 0.05 level $=9.49$

Table 4 shows the calculated value of $\chi^{2}$ was 70.10 which is greater than the table value at 0.05 levels. The prospective teachers of distance teacher education system disagreed with the statement "Written instructions are provided to prospective teachers before the commencement of teaching practice".

Table 5:TheCooperating Teachers pointed out the Deficiencies of Prospective Teachers during Teaching Practice

\begin{tabular}{lccccccc}
\hline Prospective teachers of: & $\mathrm{N}$ & SA & A & UN & DA & SDA & $\chi^{2}$ \\
\hline Distance & & 37 & 45 & 9 & 63 & 46 & 18.30 \\
$\begin{array}{l}\text { TeacherEducation } \\
\text { System }\end{array}$ & 200 & $18.5 \%$ & $22.5 \%$ & $4.5 \%$ & $31.5 \%$ & $23 \%$ & \\
\hline
\end{tabular}

* Significant $\mathrm{df}=4 \quad$ Table value at 0.05 level $=9.49$

Table 5 shows that the calculated value of $\chi^{2}$ was 18.30 which are greater than the table value at 0.05 level. The prospective teachers of distance teacher education system agreed with the statement "The cooperating teachers pointed out the deficiencies of prospective teachers during teaching practice".

Table 6: Supervisors Remained Present in Classes during Teaching Practice

\begin{tabular}{lccccccc}
\hline Prospective teachers of: & N & SA & A & UN & DA & SDA & $\chi^{2}$ \\
\hline Distance & & 41 & 54 & 11 & 65 & 29 & 15.70 \\
$\begin{array}{l}\text { TeacherEducation } \\
\text { System }\end{array}$ & 200 & $20.5 \%$ & $27 \%$ & $5.5 \%$ & $32.5 \%$ & $14.5 \%$ & \\
\hline
\end{tabular}

* Significant $\mathrm{df}=4 \quad$ Table value at 0.05 level $=9.49$

Table 6 shows that the calculated value of $\chi^{2}$ was found to be 15.70 which is greater than the table value at 0.05 level. Prospective teachers of distance teacher education system disagreed with the statement "Supervisors remained present in classes during teaching practice". 
Table 7: School administration or head of school is involved in the evaluation of prospective teachers

\begin{tabular}{lccccccc}
\hline Prospective teachers of: & N & SA & A & UN & DA & SDA & $\chi^{2}$ \\
\hline Distance & & 7 & 30 & 6 & 102 & 55 & 10.1 \\
$\begin{array}{l}\text { TeacherEducation } \\
\text { System }\end{array}$ & 200 & $3.5 \%$ & $15 \%$ & $3 \%$ & $51 \%$ & $27.5 \%$ & \\
\hline
\end{tabular}

* Significant $\quad \mathrm{df}=4 \quad$ Table value at 0.05 level $=9.49$

Table 7 shows the calculated value of $\chi^{2}$ as 10.1 which is greater than the table value at 0.05 level and the trend of respondents was towards disagreement. Hence, the statement "School administration or head of school is involved in the evaluation of prospective teachers" was rejected.

Table 8: Supervisors and cooperating teachers judge the portfolios

\begin{tabular}{lccccccc}
\hline Prospective teachers of: & N & SA & A & UN & DA & SDA & $\chi^{2}$ \\
\hline Distance & & 12 & 29 & 6 & 95 & 58 & \\
TeacherEducation & 200 & $6 \%$ & $14.5 \%$ & $3 \%$ & $47.5 \%$ & $29 \%$ & 61.8 \\
System & & & & & &
\end{tabular}

* Significant $\quad \mathrm{df}=4 \quad$ Table value at 0.05 level $=9.49$

Table 8 shows the calculated value of $\chi^{2}$ as 61.8 which is greater than the table value at 0.05 level. Prospective teachers of distance teacher education system disagreed with the statement "Supervisors and cooperating teachers judge the portfolios".

Table 9:Constant feedback is given to the prospective teachers during observation by supervisor

\begin{tabular}{lccccccc}
\hline Prospective teachers of: & N & SA & A & UN & DA & SDA & $\chi^{2}$ \\
\hline Distance & & 19 & 33 & 6 & 98 & 44 & 63.1 \\
$\begin{array}{l}\text { TeacherEducation } \\
\text { System }\end{array}$ & 200 & $9.5 \%$ & $16.5 \%$ & $3 \%$ & $49 \%$ & $22 \%$ & \\
\hline
\end{tabular}

* Significant $\quad \mathrm{df}=4 \quad$ Table value at 0.05 level $=9.49$

Table 9 shows the calculated value of $\chi^{2}$ as 63.1 which is greater than the table value at 0.05 level. Prospective teachers of distance teacher education system disagreed with the statement "Constant feedback is given to the prospective teachers during observation by supervisor".

\section{Supervisors' Opinion of Distance Teacher Education System}

Table 10: You are satisfied with the existing system of teaching practice

\begin{tabular}{lccccccc}
\hline Supervisors of: & N & SA & A & UN & DA & SDA & $\chi^{2}$ \\
\hline Distance & & 6 & 13 & 1 & 58 & 22 & 5.4 \\
$\begin{array}{l}\text { TeacherEducation } \\
\text { System }\end{array}$ & 100 & $6 \%$ & $13 \%$ & $1 \%$ & $58 \%$ & $22 \%$ & \\
Non-Significant & $\mathrm{df}=4$ & & Table value at 0.05 level $=9.49$
\end{tabular}


Table 10 shows the calculated value of $\chi^{2}$ was 5.4 which is less than table value at 0.05 level as the trend of respondents is toward disagreement. The statement "You are satisfied with the existing system of teaching practice" is rejected. This shows that Supervisors of distance teacher education system are not satisfied with the existing system of teaching practice.

Table 11: Supervisors are given proper training before conducting teaching practice

\begin{tabular}{lccccccc}
\hline Supervisors of: & N & SA & A & UN & DA & SDA & $\chi^{2}$ \\
\hline $\begin{array}{l}\text { Distance } \\
\text { TeacherEducation }\end{array}$ & 100 & 5 & 10 & 5 & 60 & 20 & $\mathbf{2 5 . 2}$ \\
System & & $5 \%$ & $10 \%$ & $5 \%$ & $60 \%$ & $20 \%$ & \\
\hline
\end{tabular}

* Significant $\mathrm{df}=4 \quad$ Table value at 0.05 level $=9.49$

Table 11 shows the calculated value of $\chi^{2}$ was 25.2 which is greater than table value at 0.05 level as the trend of respondents is toward disagreement. The statement "Supervisors are given proper training before conducting teaching practice of prospective teachers" is rejected. This shows that supervisors of distance teacher education system are not satisfied with the training before conducting teaching practice.

Table 12: You are provided with the evaluation criteria of teaching practice of your institution

\begin{tabular}{lccccccc}
\hline Supervisors of: & N & SA & A & UN & DA & SDA & $\chi^{2}$ \\
\hline Distance & & 14 & 46 & 4 & 28 & 8 & 3.2 \\
TeacherEducation & 100 & $14 \%$ & $46 \%$ & $4 \%$ & $28 \%$ & $8 \%$ & \\
System & & & & &
\end{tabular}

Non-Significant $\quad \mathrm{df}=4 \quad$ Table value at 0.05 level $=9.49$

Table 12 shows the calculated value of $\chi^{2}$ was 3.2 which is less than table value at 0.05 level as the trend of respondents is toward agreement. This shows that Supervisors of distance teacher education system agreed that they are provided with the evaluation criteria of teaching practice frominstitution.

Table 13: Prospective teachers are assessed by their selection of appropriate and relevant teaching materials

\begin{tabular}{lccccccc}
\hline Supervisors of: & $\mathrm{N}$ & $\mathrm{SA}$ & $\mathrm{A}$ & $\mathrm{UN}$ & $\mathrm{DA}$ & $\mathrm{SDA}$ & $\chi^{2}$ \\
\hline Distance & & 18 & 55 & 1 & 18 & 8 & 2.28 \\
$\begin{array}{l}\text { TeacherEducation } \\
\text { System }\end{array}$ & 100 & $18 \%$ & $55 \%$ & $1 \%$ & $18 \%$ & $8 \%$ & \\
\hline Non-Significant & $\mathrm{df}=4$ & \multicolumn{5}{c}{ Table value at 0.05 level $=9.49$}
\end{tabular}

Table 13 shows the calculated value of $\chi^{2}$ was 2.28 which is less than table value at 0.05 level as the trend of respondents is toward disagreement. The statement "Prospective teachers are assessed by their selection of appropriate and relevant teaching materials" is rejected. This shows that supervisors of distance teacher education system are not in favour of above statement. 
Table 14:The prospective teachers are awarded with the grades $A, B, C, D$.

\begin{tabular}{lccccccc}
\hline Supervisors of: & N & SA & A & UN & DA & SDA & $\chi^{2}$ \\
\hline Distance & & 12 & 65 & 2 & 17 & 4 & 15.20 \\
TeacherEducation & 100 & $12 \%$ & $65 \%$ & $2 \%$ & $17 \%$ & $4 \%$ & \\
System & & & & &
\end{tabular}

* Significant $\quad \mathrm{df}=4 \quad$ Table value at 0.05 level $=9.49$

Table 14 shows the calculated value of $\chi^{2}$ was 15.20 which is greater than table value at 0.05 level as the trend of respondents is toward agreement. This shows that the supervisors of distance teacher education system agreed that the prospective teachers are awarded with the grades A, B, C, D.

Table 15: The grading of prospective teachers is done on NPSTP (National Professional Standards for Teachers in Pakistan).

\begin{tabular}{lccccccc}
\hline Supervisors of: & $\mathrm{N}$ & $\mathrm{SA}$ & $\mathrm{A}$ & $\mathrm{UN}$ & $\mathrm{DA}$ & SDA & $\chi^{2}$ \\
\hline Distance Teacher & \multirow{2}{*}{100} & 14 & 55 & 11 & 16 & 4 & \multirow{2}{*}{11.7} \\
Education System & & $14 \%$ & $55 \%$ & $11 \%$ & $16 \%$ & $4 \%$ & \\
$*$ Significant & $\mathrm{df}=4$ & & Table value at 0.05 level= & T.49
\end{tabular}

Table 15 shows the calculated value of $\chi^{2}$ was 11.7 which is greater than table value at 0.05 level as the trend of respondents is toward agreement. This shows that the supervisors of distance teacher education system agreed that the grading of prospective teachers is done on NPSTP (National Professional Standards for Teachers in Pakistan).

\section{Major Weaknesses in Existing Teaching Practice (Qualitative Analysis)}

Most of the respondents agreed that there are various major weaknesses in existing teaching practice in formal and non-formal system. The list of major weaknesses that were prominent by respondents is given below.

Distance Teacher Education System Major Weaknesses

1. Improper lesson planning (43\%)

2. Ratio of supervisor and prospective teacher is inadequate $(55 \%)$

3. Emphasis on concerned subject content is rare (69\%)

4. Lack of qualified supervisor. (32\%)

5. Duration of teaching practice is not enough. (95\%)

6. Prospective teachers should be given more attention on preparation of A.V aids. $(71 \%)$

7. Prospective teachers are not evaluated properly. (64\%)

8. There is no external system involvement in evaluation. (41\%)

9. Evaluation method is not standardized. (23\%)

10. All aspects of evaluation are not focused. (42\%)

\section{Suggestions to Overcome Existing Shortcomings in Teaching Practice}

Most of the respondents agreed about suggestions to overcome existing shortcomings in teaching practice. Major suggestions that were considered obvious by respondents are given below.

1. Ratio of supervisor and prospective teachers should be increased. (26\%) 
2. Emphasis should be laid on concerned subject matter. (31\%)

3. Use of modern technology should be compulsory during lesson planning and teaching. (47\%)

4. Concerned institutions should be allocated specific budget for teaching practice. $(64 \%)$

5. Supervisors should be trained. (52\%)

6. A.V aids must be prepared and used by the prospective teachers. (74\%)

7. Training of supervisor \& cooperating teachers is a need of the day. (55\%)

8. Duration of teaching practice must be increased or it must be 15 days in each semester. $(91 \%)$

9. Some external evaluators should be involved. (31\%)

10. Standardized system of evaluation must be introduced. (15\%)

11. Each aspect required for effective teaching must be focused in evaluation of teaching practice. $(36 \%)$

\section{Discussion and Conclusion}

This study was undertaken to find out the evaluation methods of teaching practice of distance teacher education systemin Pakistan. This study explored the methods of evaluation of teaching practice used by distance teacher education system. Moreover, it was intended to provide the weaknesses and strengths of different evaluation methods used by this system of education.

The findings of this research study suggested that there must be training of cooperating teachers and university supervisors should be oriented before commencement of teaching practice. This is similar to the findings of Kiggundu .Edith and Samuel (2009) as they also recommended that teacher education institutions should organize workshops to empower and support mentors i.e. supervisors and cooperating teachers. Similarly, Maphosa et. Al. (2009) suggested that supervisors and cooperating teachers should be constantly empowered through workshops in leading and guiding prospective teachers.

In this research study, the prospective teachers as well as supervisors of both the systems viewed that manual of rules and regulation of teaching practice was provided to them by university before the commencement of teaching practice. Prospective teachers of both the systems intended that suitable arrangements were provided by the school management for teaching practice. But Gujjar et. Al. (2010) concluded in his research study that manual of rules and regulations of teaching practice and evaluation criteria were not provided to the prospective teachers before starting the teaching practice. Some institutions informed them with the evaluation criteria while some institutions did not give any information to the prospective teachers regarding evaluation which created anxiety among them. This was in line with the study of Bhargava Anupama (2009) in which she mentioned about evaluation anxiety. She considered it a major issue which causes discomfort to the prospective teachers. In evaluation methods of teaching practice in distance teacher education institution of Pakistan, it was revealed that the evaluation methods of teaching practice in distance teacher education system are not continuous and less comprehensive. In distance teacher education system, the prospective teachers focused only on the final lesson (as they are evaluated at once during this final lesson). The role of supervisor and prospective teacher in distance teacher education system is less active. Cooperating teacher is not involved in evaluation of teaching practice in distance teacher education system whereas in some formal system institutions, the head and cooperating teachers are getting involved. 
It is concluded that prospective teachers and supervisors of distance teacher education universities opined that prospective teachers were awarded with A, B, C, D grades. Some of them reported that they were awarded fail and pass at the end of teaching practice according to National Professional Standard for Teachers in Pakistan (NPSTP). Majority of supervisors of both the system viewed that supervisor involved the cooperating teachers in evaluation; they checked and gave their remarks on lesson plans for their improvement. As compared to supervisors of formal universities, majority of supervisors of distance teacher education universities opined that there was no involvement of school administration. Guidance of supervisors, teacher's written reflection in the portfolio, professional relationship with school staff and prospective teachers and constant compulsory feedback were not given to prospective teachers. Majority of distance teacher education universities supervisors opined that supervisor and cooperating teachers judged the portfolio, provided guidance in developing the professional portfolio and cooperative teacher gave feedback to prospective teachers. Moreover, supervisors stayed in practicing school for the whole day to convey written feedback to the prospective teacher.

\section{Recommendations}

On the basis of findings and conclusions, following recommendations were made:

1. Intentions of respondents of distance teacher education universities showed that they were not satisfied with the quality of existing teaching practice. It is therefore, recommended that quality of teaching practice should be improved. This is possible after giving due consideration to all elements of teaching practice. The major elements include duration of teaching practice, teaching of different allied subjects and opportunities to prospective teachers to use different methods of teaching in a real classroom setting.

2. The opinions of the prospective teachers of distance teacher education universities revealed that self-evaluation of prospective teacher was not an essential part of teaching practice. Elements like micro teaching, skill to give individual attention to every student, application of new knowledge or ideas and use of various evaluation techniques in the class were not considered by prospective teachers. It is therefore, recommended that all these elements should be followed by the prospective teachers during their practice.

3. The opinions of respondents of distance teacher education universities reveal that supervisors did not guide the prospective teachers properly. It is therefore, recommended that the authorities of distance teacher education universities should make it possible to ensure supervisor's guidance for prospective teachers proper and up to the mark.

\section{References}

Akbar, R.A. (2002). A study of Teaching Practice of Prospective Secondary School Teachers and Development of Teaching practice Model, Arid Agriculture University, Rawalpindi.

Ali. Murtaza. (2005). Comparative Study of Teaching Practice in Formal and Non formal System and development of a Model, Arid Agriculture University, Rawalpindi. (Unpublished PhD thesis).

Eraut, M. (2000) Non-formal learning, implicit learning and tacit knowledge, in F. Coffield(Ed) The necessity of Informal learning: Policy Press. Bristol. 
Gay, L.R. and Airasian, P. (2003). Educational Research: Competencies for analysis and application. New Jersey: Merril.

Goe, L., Bell, C. and Little, D. (2008). Approaches to Evaluating teacher Effectiveness: A Research Synthesis. National Comprehensive centre for Teacher Quality. Durham University. The Sutton Trust.

Nomikou,M.(2008). The impact of Non-Formal Education on young people and society: AEGEEEurope, Rue Nestor de Tiere 15, 1030 chaarbeek/Brussels, Belgium.

Onyekan, (2000). What is Student Teaching Practice? In National Open University of Nigeria: Edu 635 Teaching Practice Manual. Available at http://www.nou. edu.nq/noun/NOUNOCL.

Saeed. M. (2002). Impact evaluation of 5-day teaching skills development course for primary school teachers in Punjab. Journal of Elementary Education, 12(1), 36-44.

Taneja, R. P. (2000). Encyclopedia of Comparative Education, Vol. 4. Anmol Publications Pvt. Ltd, New Delhi. 